DOI: $10.15503 /$ jecs20151.20.25

\title{
THE COURAGE TO BE ANXIOUS. PAUL TILLICH'S EXISTENTIAL INTERPRETATION OF ANXIETY
}

\author{
ŞTEFAN Bolea \\ Babeş-Bolyai University, Faculty of Letters, \\ Strada Mihail Kogălniceanu 1, Cluj-Napoca 400084, Romania \\ stefan.bolea@gmail.com
}

\begin{abstract}
The similitude between anxiety and death is the starting point of Paul Tillich's analysis from The Courage To Be, his famous theological and philosophical reply to Martin Heidegger's Being And Time. Not only Tillich and Heidegger are concerned with the connection between anxiety and death but also other proponents of both existentialism and nihilism like Friedrich Nietzsche, Emil Cioran and Lev Shestov. Tillich observes that "anxiety puts frightening masks" over things and perhaps this definition is its finest contribution to the spectacular phenomenology of anxiety. Moreover, Tillich has some illuminating insights about the anxiety of emptiness and meaninglessness, which are important for the history of the existential philosophy. It is interesting how the protestant theologian tries to answer to Heidegger: while the German philosopher asserted that we must avoid fear and we have to embrace anxiety as a route to personal authenticity, Tillich notes that we should transform anxiety into fear, because courage is more likely to "abolish" fear.

Keywords: anxiety, fear, courage, death, existentialism, phenomenology, existentialism, nihilism, meontology, meaninglessness, authenticity
\end{abstract}

\section{ANXIETY BETWEEN NIHILISM AND EXISTENTIALISM}

The existential theologian Paul Tillich starts his phenomenology of anxiety from this definition: "anxiety is the existential awareness of nonbeing" (Tillich, 1952, p. 35). One could say that through anxiety - seen as a cognitive modality nonbeing impresses itself upon the structure of the human being. Of course, this is a sort of paradoxical knowledge because nonbeing might be deceptive (one could assign to it the so-called "cunning" [List] famously ascribed to reason) (Hegel, 1975 , p. 89); this knowledge discloses itself only partially and never decisively. The "revelations" of nonbeing (the knowledge the human being steals from nothingness, a poisoned and harmful awareness), through their constitutive ambiguity, lead the human consciousness to a state of inebriation: the images of the vertigo and dizziness are expressions of this situation. We enter the territory covered by Lev Shestov in his intriguing work, In Job's Balances. Commenting on Euripides, the Russian philosopher remarks: "What can be more terrible than not to know whether one is alive or dead?" (Shestov, 1975, p. 3).

The secondary definitions built by Tillich are linked to the aforementioned founding definition. The American theologian amplifies them in the following manner: 
anxiety is "finitude, experienced as one's own finitude" (Tillich, 1952, p. 35) and "the state in which a being is aware of its possible nonbeing" (Tillich, 1952, p. 35). Although the German born philosopher considers that anxiety can never be considered as a form of "abstract knowledge" (Tillich, 1952, p. 35), we could redefine it in our own terms as an impression of the unknown into the known. Moreover, we could use anxiety as the primary tool in a method of thanatological epistemology, responsible for the element "death" from the "being-towards-death" (Heidegger, 1978, pp. 279303). The main principle of this epistemology could never be a rational one. On the contrary, it argues for the complete separation between logic and psychology in the exploitation of the paradoxical emotion of anxiety.

Heidegger makes it clear that the anticipatory constitution of the being-towards-death (Heidegger, 1978, p. 306) is not morbid. However, as a hypothesis, we can imagine anxiety as a border concept, through which the meontological impresses itself upon the Dasein or, otherwise said, the nonbeing captures some of being's territory. Shestov and Cioran lead us to this nihilist domain because this meontological impression (or the fingerprint of nothingness) presupposes a mixture of death and life: "The true sense of agony seems to me to lie in the revelation of death's immanence in life" (Cioran, 1992, p. 23).

A methodological observation is necessary here: to reinforce the dialogue between life and death and the inwardness between vitalism and thanatology one does not need the Schopenhauerian notion of pain (the starting point of both Nietzsche's and Cioran's philosophies); one can transcend the phenomenology of pain through the careful exploitation of the more subtle and more original anxiety. The peratological motivation of anxiety starts from this new way of looking at it, as an epistemological method of "studying" the unknown. We can highlight here the liaison between psychology and mysticism: these two fields are explored by both Cioran and Shestov. The concept of anxiety surpasses the anticipatory function of death, becoming an outpost of mortality. It excludes all life forms and replaces them with death, expressing the "dark night of the soul" [noche oscura] described by San Juan de la Cruz.

This night of the soul was experienced by the protoexistentialist Pascal, who understood that the order of the affects transcends the order of reason and that the heart can (de)structure the personality according to the revelations stolen from nonbeing. Through anxiety (and perhaps a similar argument can be built up for pain) we experience death while still alive. Cioran and Heidegger would both agree (although from slightly different perspectives) that thanatology is at the core of existence, that "death is the heart of life", that awareness of our own mortality leads to responsible acceptance of our existence. Still: living with death means living in anxiety. Moreover, death anxiety marks us and transforms us into living tombs. It is a form of askesis, when we ask ourselves: how much death can we endure? It is also a form of existential trauma: anxiety is not only the route to authenticity (as both Heidegger and Sartre argue), but also a way the experience being-towards-death. "Death's immanence in life" (Cioran, 1992, p. 23) can shut down our lively hopes and expectations and change us into existential corpses, "too dead to die" and unable to return to life as well. Like the frozen mask of 
Medusa, anxiety can be a "killer": and in the manner of the shivering "hand of death", anxiety paralyzes us as it poisons our souls.

Coming back to Tillich, we can understand his conception upon anxiety from the following quote: "Our anxiety puts frightening masks over all men and things. If we strip them of these masks their own countenance appears and the fear they produce disappears [...] It is our uncontrolled desires that create masks and put them over men and things" (Tillich, 1952, pp. 13-14). The Christian philosopher presents a spectacular conception of the existential subject: the objects of anxiety have a persona (an avatar we would say today), through which they receive the power to frighten. In this line of argumentation, the theater of anxiety is that interactive "spectacle" in which the masks of anxiety besiege the soul and threaten it with destruction.

One can easily see that the assault of anxiety brings with it an infernal dramatization; unfortunately not a Medieval Danteesque ceremony (where the subject is technically separated from the tortures of the damned), but a Renaissance spectacle, where the anguished self is surrounded by the threatening avatars and executed like Marlowe's famous character, Faustus:

Ah, Faustus,

Now hast thou but one bare hour to live,

And then thou must be damn'd perpetually!

Stand still, you ever-moving spheres of heaven,

That time may cease, and midnight never come ...

O lente, lente currite, noctis equi!

The stars move still, time runs, the clock will strike,

The devil will come, and Faustus must be damn'd.

(Marlowe, 2003, p. 393)

A certain destiny would lead the one harassed by anxiety to total collapse: psychology, although differently understanding existential anxiety, proves that this is not impossible. Tillich offers his dramatic example, suggesting a solution as well: the unmasking of the threatening avatars (which usually disguise our greedy desires) diminishes panic. Coming back to our personified anxieties, one could observe that the unmasking of the anxiety objects transforms enemies into allies, disclosing what hides beneath the mask. Therefore, we should remove the things which block our perspective: if we vanquished the painful ordeal of anxiety, we would embrace clarity (Castaneda, 1972, p. 58).

\section{ANXIETY OF MEANINGLESSNESS}

Tillich shows that there are three types of anxiety (of fate and death, of emptiness and meaninglessness and of guilt and condemnation). We shall focus specifically on the anxiety of emptiness and meaninglessness because it is an important bridge between nihilism and existentialism. This type of anxiety presented by Tillich can be introduced by the Nietzschean diagnosis from The Will To Power: "What does nihilism mean? That the highest values devaluate themselves. The aim is lacking; "why? « finds no answer" (Nietzsche, 1968, p. 9). When a human being feels that his life has no meaning, 
he loses his fundamental motivation to express himself, because his capacity for self-creation is threatened. The "why" never finding an answer hinders the possibility to believe in any kind of meaning. A problem intimately connected with that of nihilism (understood as a void of meaninglessness) is the philosophy of absurdity explored by Albert Camus. In a line of argument that vividly describes our post-modern condition (although these remarks were written in 1942), the French writer notes:

Rising, streetcar, four hours in the office or the factory, meal, streetcar, four hours of work, meal, sleep, and Monday Tuesday Wednesday Thursday Friday and Saturday according to the same rhythm - this path is easily followed most of the time. But one day the "why" arises and everything begins in that weariness tinged with amazement. "Begins" - this is important. Weariness comes at the end of the acts of a mechanical life, but at the same time it inaugurates the impulse of consciousness (Camus, 1955, p. 10).

The exasperation of an existence dominated by the work routine - an irritating necessity in itself - provokes at a certain time the unsolvable Nietzschean "why" that can find no certain answer. However, we aren't at all convinced that "weariness" can trigger "the impulse of consciousness", because its most likely companion is a media-controlled "sleep" which cancels the possibility of awareness. Coming back to Tillich, we should note that "the anxiety of meaninglessness is anxiety about the loss of an ultimate concern, of a meaning which gives meaning to all meanings" (Tillich, 1952, p. 47). A "spiritual center" (Tillich, 1952, p. 47) has faded away: obviously our Protestant theologian alludes to the waves of secularization that highlight his historical moment (i.e. the post-war existential anguish). One might ask: can we still be Christians after Hiroshima and Auschwitz or have these versions of secular apocalypse transformed our very structure? Can we be still humanists after we have sent into nothingness our fellow human beings? Do we still survive after a metaphorical collective suicide?

We have defined elsewhere existentialism as a "soul doctor of a »nihilism-infected " world" (Bolea, 2014, p. 65) that seeks to cure a society driven to collective psychosis by the Second World War. Paul Tillich describes the symptoms of nihilism in order to find an existentialist solution to this crisis of meaning: "Emptiness and loss of meaning are expressions of the threat of nonbeing to the spiritual life. This threat is implied in man's finitude and actualized by man's estrangement. It can be described in terms of [...] total doubt [...]" (Tillich, 1952, p. 48). The force of "nonbeing" which makes us aware of our "finitude" and "estrangement" consists in the "total doubt" which has nothing to do with the Cartesian methodological doubt: this version of doubt sentences the human subject to an existential inferno, where he is separated from his very being, alienated from his creativity and sense of purpose. His ordeal is so painful that the human being, in trying to fight the mortifying forces of this personal inferno, "flees from his freedom", "surrendering" himself (Tillich, 1952, p. 49). Like Heidegger and Sartre before him, Tillich shows that we embrace the defense mechanisms of inauthenticity in order to fight the terrifying anxiety of meaninglessness. If his predecessors spoke of "they-self" or "bad faith", the German-American theologian refers to inauthenticity as "something transindi- 
vidual". This "escape from freedom" (to use Erich Fromm's famous title) is an actual "destruction" of the human being, who departs from an important fragment of his individuality trying to reprogram himself in terms of transindividuality: one can think of the process of betraying our true beliefs in order to fit in or to suppress our personality because the requirements of the group call for this defection.

\section{CHOOSING ANXIETY OVER FEAR?}

It is a well-known fact that Tillich conceived his Courage To Be as a reply to Heidegger's masterpiece: Being And Time. The most significant divergence between the two philosophers is their treatment of the distinction between fear and anxiety. Heidegger conceived anxiety as a "fallen" anxiety, as a missed opportunity to be authentic: "Fear is anxiety, fallen into the »world «, inauthentic, and, as such, hidden from itself" (Heidegger, 1978, p. 234). Tillich's opinion is entirely different: "We try to transform the anxiety into fear and to meet courageously the objects in which the threat is embodied. We succeed partly, but somehow we are aware of the fact that it is not these objects with which we struggle that produce the anxiety but the human situation as such" (Tillich, 1952, p. 45). We have to admit the solution of the existential theologian is ingenious: starting from Kierkegaard's revolutionary insight, who showed that anxiety has no object and that - therefore - nothing(ness) is its source (Kierkegaard, 1980, p. 41), Tillich claims that we may »disarm « anxiety by turning it into fear. There are a number of weapons we can use against fear as common sense teaches us: on the contrary, courage dissolves under the ambiguous and veiled action of anxiety. Maybe this operation is inauthentic in Heideggerian sense but in moments of crisis, the Tillich solution has a huge practical value.

Starting from the "Tillich method" of replacing anxiety with fear, we might devise another defense mechanism against anxiety, influenced by a nihilistic methodology which should be called fight fire with fire. It presupposes the great mental effort of replacing a particular anxiety with another anxiety. Considering that we recognize anxiety, despite its lack of object (e.g. I fear the fear ${ }^{11}$ of death) we can replace it from the huge variety of personalized anxieties with another one, just as indeterminate (e.g. I fear the fear of pain). This method requires a high-achieving psychology mechanism, through which we acknowledge anxieties by our inner vision. Because they are objectless, they can only be identified only after a certain "color": it is essential to classify them according to those "colors" in order to fight them. For example, the anxiety we are accustomed to is easier to fight than that which comes unexpectedly. We cannot build an epistemology at this point, because the cognitive aspects are paralyzed by the lack of object; but we can hope for a certain intuition, which replaces the vagueness of a certain unknown anxiety with the familiar taste of one we are accustomed to live with.

Do we possess the courage to be anxious? Or should we always try - as Tillich urges us - "to transform anxiety into fear"? Considering that the nihilistic situation of the fear offear of ... refers to a labyrinthine anxiety, which clones itself and advances to a higher stage, one might appeal to an anxiophilic mentality, described for instance

11 Here anxiety is redefined in an existentialist fashion as a fear of fear. 
by Charles Baudelaire: "He speaks of a duel in which the artist, just before being beaten, screams in fright. This duel is the creative process itself. Thus Baudelaire placed the shock experience at the very center of his artistic work" (Benjamin, 2009, p. 40). The subject of anxiety can reach a state of catatonic ataraxia, a sort of infernal "no exit", transgressing the cycle of anxiety and defense mechanism, being effectively crushed (but freed at the same time) by the recoil of successive shocks. Can one live in this nirvana of being, in this emotional no man's land? Not quite but one can outlive anxiety, through this absolute repetition, which immunizes the subject.

\section{CONCLUSION: THE DOUBLE NEGATION OF BEING}

We would like to note also the inciting dialectic between being and nonbeing from the last chapters of The Courage To Be, which highlights the kinship between the two contradictory concepts: "Being affirms itself against nonbeing [...] The self-affirmation of being without nonbeing would not even be self-affirmation but an immovable self-identity" (Tillich, 1952, p. 179). In other words, being needs nonbeing to affirm itself, otherwise its immobility would be sterile: "Nonbeing drives being out of its seclusion, it forces it to affirm itself dynamically" (Tillich, 1952, p. 179). Nonbeing is the beginning of the progression, the evolutionary impulse, the caesura which pierces being and forces it to react and create itself. Moreover, "we could not even think »being « without a double negation: being must be thought as the negation of the negation of being" (Tillich, 1952, p. 179). In order to conceive being as a "negation of the negation of being", the couple negation+nonbeing must be conceived as the star of an (post-)existential philosophy. One might observe that "a deeper philosophy of being could be built as a conversation with nihilism" (Bolea, 2008, p. 179) and that, starting from the insights of the Protestant theologian, meontology could be understood as the driving force and the subterranean spark of fundamental ontology.

\section{REFERENCES}

Benjamin, W. (2009). On Some Motifs in Baudelaire. In: M. Damon, \& I. Livingstone (Eds.), Poetry And Cultural Studies. A Reader (pp. 37-55). Chicago: University of Illinois Press.

Bolea, S. (2008). Nihilism and the Problem of Being. Transdisciplinarity in Science and Religion, 3, 173-182.

Bolea, S. (2014). What is Existentialism? A Revision of Contemporary Definitions. Studia UBB. Philosophia, Vol. 59 No. 2, 63-72.

Camus, A. (1955). The Myth of Sysiphus and Other Essays. Translated by J. O'Brien. New York: Vintage Books.

Castaneda, C. (1972). The Teachings of Don Juan. A Yaqui Way of Knowledge. Berekeley: University of California Press.

Cioran, E. M. (1992). On the Heights of Despair. Translated by I. Zarifopol-Johnston. Chicago: The University of Chicago Press.

Hegel, G. W. F. (1975). Lectures on the Philosophy of World History. Translated by H. B. Nisbet. New York: Cambridge University Press.

Heidegger, M. (1978). Being And Time. Translated by J. Macquarrie, \& E. Robinson. Oxford: Blackwell.

Kierkegaard, S. (1980). The Concept of Anxiety. Edited and translated by R. Thomte, \& A. B. Anderson. Princeton, NJ: Princeton University Press.

Marlowe, Ch. (2003). The Complete Plays. Edited by F. Romany, \& R. Lindsey. London: Penguin Classics.

Nietzsche, F. (1969). The Will To Power. Translated by W. Kafmann, \& R. J. Hollingdale. New York: Vintage Books.

Shestov, L. (1975). In Job's Balances. On the Sources of the Eternal Truths. Athens, OH: Ohio University Press. Tillich, P. (1952). The Courage to Be. New Haven, CT: Yale University Press. 